\title{
Maize Crop N Uptake from Organic Material of Gliricidia sepium Coinoculated with Rhizobium and Arbuscular Mycorrhizal Fungus in Sub-Saharian Africa Sandy Soil
}

\author{
Adama Diouf ${ }^{1,2 *}$, Malick Ndiaye1, Mame Arama Fall-Ndiaye1, Tahir Abdoulaye Diop1 \\ ${ }^{1}$ Laboratoire de Biotechnologies des Champignons, Département de Biologie Végétale, Faculté des Sciences et Techniques, \\ Université Cheikh Anta Diop, Dakar, Sénégal \\ ${ }^{2}$ Laboratoire Commun de Microbiologie IRD/ISRA/UCAD, Centre de Recherche de Bel Air, Dakar, Sénégal \\ Email: ^adama1.diouf@ucad.edu.sn
}

How to cite this paper: Diouf, A., Ndiaye, M., Fall-Ndiaye, M.A. and Diop, T.A. (2017) Maize Crop N Uptake from Organic Material of Gliricidia sepium Coinoculated with Rhizobium and Arbuscular Mycorrhizal Fungus in Sub-Saharian Africa Sandy Soil. American Journal of Plant Sciences, 8, 428-440. https://doi.org/10.4236/ajps.2017.83029

Received: October 31, 2016

Accepted: February 4, 2017

Published: February 7, 2017

Copyright (c) 2017 by authors and Scientific Research Publishing Inc. This work is licensed under the Creative Commons Attribution International License (CC BY 4.0).

http://creativecommons.org/licenses/by/4.0/

\begin{abstract}
The effect of green manure of gliricidia (Gliricidia sepium (Jacq.) Walp) leguminous plants applied for cereal maize cultivation and $\mathrm{N}$ uptake by cereal were investigated and analyzed in relation to influence of dual inoculation of gliricidia with microbial symbionts. Two pot experiments were conducted in greenhouse. The first trial was set up to enhance growth of gliricidia with exotic and indigenous rhizobial strains and arbuscular mycorrhizal fungus and the second to determine the effect of gliricidia organic material on maize growth. Direct $15 \mathrm{~N}$-labelling techniques were used to estimate $\mathrm{N}$-fixed by gliricidia plant and $\mathrm{N}$ uptake of maize cereal crop from green manuring was calculated. Growth of gliricidia trees estimated by aboveground biomass production and $\mathrm{N}$ fixed were positively affected by dual inoculations. This study showed that shoot dry weight and $\mathrm{N}$ accumulation of maize cultivated under gliricidia green manure were influenced by its application and indirectly by microbial treatments. The $\mathrm{N}$ recovery by the maize accounted $17.32 \%$ to $26.52 \%$ of $\mathrm{N}$ applied as gliricidia organic material. Gliricidia green manure $\mathrm{N}$ accumulation and release, and afterward microbial inoculations were substantially determining on maize crop $\mathrm{N}$ uptake and growth in sandy soil of Sub-Saharian Africa.
\end{abstract}

\section{Keywords}

Arbuscular Mycorrhizal Fungus, Green Manure, Maize, Nitrogen, Rhizobium

\section{Introduction}

In Sub-saharian Africa, the removal of crop residues from fields is one of the 
main facts which contribute to soil negative nutrient balances. The decline in availability of nutrients, especially $\mathrm{N}$, has not been mitigated by the use of chemical fertilizers [1]. Many management practices such as cropping system, soil tillage and application of mineral and organic soil amendments are proposed worldwide to solve this problem [2]. The promotion of sustainable agriculture can be based on the recycling of organic resources.Traditionally sustainable agriculture is adopted in farmer practices by managing organic resources as nutrient sources in different ways. Kidd et al. (2007) reported organic materials used as soil amendments to increase or replace soil organic matter instead of inorganic fertilizer to supply essential plant nutrients [3]. Because of soil improvement on $\mathrm{N}$-deficient by inorganic $\mathrm{N}$ fertilizer in small holder farmers caused enormous environmental damage in sandy soil, the application of organic matter amendments was the appropriate system for nutrient supply. Bationo et al. (2008) reported that organic inputs maintain the physical and chemical components contributing to soil fertility such as cation exchange capacity and soil structure [4]. Tree pruning and green manuring practice are known to improve soil physico-chemical and biological properties by directly providing plant available nutrients through mineralization [5]. Nodulated legumes contribute significantly to the $\mathrm{N}$ economy of soil and, in so doing, increase agricultural yields of food crops. The results of Hardarson and Atkins (2003) revealed that legumes can be used as green manure thanks to their ability to fix atmospheric nitrogen [6]. Notably, use of leguminous plants contributed for a substantial part of the fixed nitrogen transferred to the soil for subsequent no fixing crop such as cereals. Additionally, leguminous plants which are a potential tool to improve soil fertility can be improved in nitrogen and phosphorus contents with microbial inoculation.

In Senegal, the sandy soil properties of the North-western costal area called Niayes zone are mainly affected by its long term use and inadequate agricultural practices. This zone constitutes the potential cash crop production for farmers due to its propitious microclimate and water availability during the long dry season. For recording high yield crops in this zone, large amount of inorganic fertilizers have to be usually applied. Unfortunately, inorganic fertilizer was not available for farmers because of its high and unsustainable cost. Thereby in addition, nitrate leaching process through the sandy soil increased risk of underground water pollution which is a public health problem. Previously, Conant et al. (2013) reported that a substantial portion of $\mathrm{N}$ inputs to croplands are not captured in harvested products and leave the field, contributing to air and water pollution [7]. To settle this deleterious situation, some Senegalese smallholders' farmers are investigating green technology such as compost and agro-forestry systems or green manure use with less or without inorganic fertilizers. Due to land use pressure related to high demographic, soil $\mathrm{N}$ decreasing and unavailability of grain legumes green manuring because of its long time land occupancy, leguminous trees were used in agroforestry systems. Gliricidia tree grown as wind breaks and field boundaries was appropriate for high amount of above- 
ground biomass production. Additionally, this introduced leguminous tree showed already a high level of $\mathrm{N}$ fixation in this area [8]. In addition, the advantages of using organic matter on soil were not solely to provide nutrients, but were often related to other beneficial impacts on organic matter addition such as soil water holding capacity and improvement of soil structure due to the effects on aggregation of soil particles and on the stimulation of biological activity in soil [4]. In previous greenhouse experiments set up in this zone, incorporation of gliricidia biomass in soil increased the $\mathrm{N}$ availability for maize crop [9]. In this study, growth and grain yield of maize plants were significantly increased when biomass of gliricidia was supplied as amendment in comparison to unfertilized plants with organic matter. A significant effect of Rhizobium and AMF inoculations on gliricidia plants for organic matter production was also observed on maize grains production.

The main objective of this research was to study the potential contribution of gliricidia green manure on $\mathrm{N}$ recovery by maize crop in the sandy soil. The specific objectives were to determine both impact of inoculations with rhizobial and arbuscular mycorrhizal strains on gliricidia growth and its subsequent influence on maize $\mathrm{N}$ uptake from green manure.

\section{Materials and Methods}

\subsection{Soil Characteristics}

The experiments were conducted under greenhouse condition at Dakar Research Station located at Bel Air (latitude $14^{\circ} 44^{\prime} \mathrm{N}$, longitude $17^{\circ} 30^{\prime} \mathrm{W}$ ). Soil used in this study was collected from Niayes zone. This soil was a sandy soil type (93\% of sand) classified as an Arenosol and presented the main following characteristics: $7.0 \mathrm{pH}, 0.025 \% \mathrm{~N}$ and $26 \mathrm{ppm}$ available $\mathrm{P}$. The soil sampled from the $0-30 \mathrm{~cm}$ topsoil was sieved $(1 \mathrm{~mm})$ and homogenised. Unsterilized soil portions $(16 \mathrm{~kg})$ containing approximately $10^{2}$ rhizobia $\mathrm{g}^{-1}$ were weighed into $30 \mathrm{~cm}$ diameter buried cylindrical containers.

\subsection{Green Manure Production from Giricidia Plants}

Seeds of G. sepium were surface scarified and sterilized for 15 min immersion in sulphuric acid and washed vigorously in sterile distilled water and germinated on water agar at $30^{\circ} \mathrm{C}$. Seedlings were transferred into container and watered daily at field capacity with tap water.

During this process, gliricidia plants were grown in a randomised block design with four replicates. Two factors were studied: i) rhizobial inoculation with four levels: strain TAL 1769 (R1, reference strain from NifTAL collection Hawaï, USA) ISRA 727 (R2, indigenous strain), mixed TAL 1769 and ISRA 727 $(\mathrm{R} 1+\mathrm{R} 2)$ and non-inoculated (R0); ii) AMF (M1, strain Rhizophagus aggregatum, Schenk and Smith and. Roske; DAOM 227,128) and non-mycorrhizal (M0) inoculation. For ${ }^{15} \mathrm{~N}$ isotope dilution techniques, the ammonium sulphate $\left({ }^{15} \mathrm{NH}_{4}\right)_{2} \mathrm{SO}_{4}$, in the form of 10 atom $\%{ }^{15} \mathrm{~N}$ excess, was applied to all labelled plants at the rate of $20 \mathrm{mg} \mathrm{N} \mathrm{kg}^{-1}$ soil. The non-nitrogen fixing tree, Cassia sia- 
mea was used as reference plant. Plant aboveground biomass dry weights were determined. Twelve weeks after sowing, the cultivated plants of gliricidia were harvested. These plant shoots were dried and ground to around $4 \mathrm{~mm}$ size for green manure after weights determining. Analysis were done from a subsample of each plant dry matters ground to $200 \mu \mathrm{m}$. Nitrogen content $(\% \mathrm{~N})$ and atom $\%$ ${ }^{15} \mathrm{~N}$ excess (\% ${ }^{15} \mathrm{Na}$.e.) were determined for each plant including the non-nitrogen fixing treeat the International Atomic Energy Agency's (IAEA) laboratory in Seibersdorf. Nitrogen fixation (\%Ndfa) was calculated using the isotope dilution equation [10].

$\% \mathrm{Ndfa}=\left(1-\left(\%^{15}\right.\right.$ Nae in fixing plant $/ \%^{15}$ Nae in non-fixing plant $\left.)\right) \times 100$.

\subsection{Maize Crop Cultivation}

The individually harvested plant shoots labelled were incorporated separately into soil in other similar cylindrical containers for maize (Zea mays) cultivation in the rate $85 \mathrm{~g} /$ plant. Ground shoots of gliricidia plants were applied separately according to different treatments. Maize grains were sown eight weeks after incorporation of $G$. sepium organic materials in soil and watered at field capacity with tap water. Maize shoot plants were harvested separately at maturity and their dry matter weighed. Maize nitrogen content $(\% \mathrm{~N})$, total $\mathrm{N}$ amount and atom $\%{ }^{15} \mathrm{~N}$ excess were determined. According to Hauck and Bremner (1976), the percentage of nitrogen derived from the added green manure as organic materials (\%Ndfgm) was calculated using the following equation [11].

$\%$ Ndfgm $=\%{ }^{15}$ Na.e.in maize crop $/ \%{ }^{15}$ Na.e in green manure added $\times 100$.

The amount of $\mathrm{N}$ derived from the green manure can be calculated as follows:

$$
\operatorname{Ndfgm}(g)=(\% \mathrm{Ndfr} / 100) \times N \text { in the crop. }
$$

The amount of nitrogen recovered by maize from the amendment by Gliricidia aboveground biomass was calculated using the following formula: $\% N$ recovery $=\operatorname{Ndfgm}(g) / N$ added as green manure $(g) \times 100$.

\subsection{Statistical Analysis}

To evaluate treatment effects, data were then statistically analysed using the software packages STAT-ITCF. A two way analysis of variance with $\mathrm{P}<0.05$ indicating a significant difference into main effects of rhizobia and AMF inoculations and interaction between them were operated.

\section{Results}

\subsection{Dry Matter, N Content and Total Nitrogen of Gliricidia}

There was no significant interaction $(\mathrm{p}<0.05)$ between rhizobial and AMF inoculations on biomass production of gliricidia plants evaluated as aboveground dry matter and total nitrogen (Table 1). Therefore, for these parameters, the main sources of variation (Rhizobium and AMF) were highly significant ( $\mathrm{p}<$ 0.001). Dry matter production was significantly affected by inoculation with 
rhizobial strains. Whatever, there were no significant difference between rhizobial strains' origines (indigenous or exotic) or the type of application (single or mixed). Thus, compared to no-inoculated plants, the shoot dry weight was higher (18.54\%) due to rhizobial inoculation effect. Otherwise, dry matter production was positively influenced by AMF application. This was confirmed by the significant increase with on average $107.5 \mathrm{~g} / \mathrm{pl}$ and $97.28 \mathrm{~g} / \mathrm{pl}$ when AMF was applied or not respectively. Table 1 indicates that rhizobial inoculation influenced significantly $\mathrm{N}$ content $(\% \mathrm{~N})$ in shoot dry matter. This $\% \mathrm{~N}$ increased highly (10.49\%) compared to no-inoculated plants. Total $\mathrm{N}$ of gliricidia biomass was significantly increased by inoculation with rhizobia and AMF in comparison to no inoculated plants (Table 1).

\section{2. ${ }^{15} \mathrm{~N}$ enrichment, Proportion and Amount of $\mathrm{N}_{2}$ Fixed by Gliricidia}

The ${ }^{15} \mathrm{~N}$ enrichment in dry matter was significantly lower on gliricidia tree than on the reference no fixing tree Cassia siamea $(0.381 \%)$ indicating that significant nitrogen fixation occurred in the fixing tree $G$. sepium. Plant ${ }^{15} \mathrm{~N}$ enrichment $\left(\%{ }^{15} \mathrm{Na} . \mathrm{e}\right)$, percent and amount $\mathrm{N}$ derived from atmosphere were significantly influenced by inoculation with both rhizobial and AMF strains with a significant interaction (Table 1). Indeed, for gliricidia plants inoculated with both Rhizobium and AMF, the proportion (\%Ndfa) and amount of $\mathrm{N}_{2}$ fixed were found at $8.40 \%$ and $35.82 \%$ higher respectively than non-inoculated plants. Thus, a positive effect of inoculations was noted on the growth of gliricidia plants which were used as green manure for the cultivation of maize.

Due to the highly significant ${ }^{15} \mathrm{~N}$ enrichment in gliricidia aboveground biomass, the labelled dry matter was used as amendment on maize cropping system. Nitrogen from this aboveground biomass to be incorporated ( $\mathrm{N}$ add) in soil for maize growth was significantly influenced by the two main factors. Compared with control, rhizobial and AMF inoculations treatments increased growth of $10.10 \%$ and $2.5 \%$ respectively (Table 1 ). So any significant interaction of inoculation treatments was observed on nitrogen added.

\subsection{Shoot Dry Matter, $\mathrm{N}$ Content, Total $\mathrm{N}$ and $\%{ }^{15} \mathrm{~N}$ Content of Maize}

Table 2 showed that no significant interaction $(\mathrm{p}<0.05 \%)$ of microbial treatments for green manure production was observed on shoot dry matter, total $\mathrm{N}$ and $\%{ }^{15} \mathrm{~N}$ content of maize crop. Therefore, these maize plant parameters shown high differences for the main factor rhizobial inoculation applied for gliricidia plants cultivation. Dry matter, $\mathrm{N}$ content $(\% \mathrm{~N})$ and atom $\%{ }^{15} \mathrm{~N}$ excess of maize cultivated in soil amended with gliricidia green manure were not statistically influenced by the effects of gliricidia plants inoculation whatever the rhizobial strains treatments. These were however, higher than those of maize cultivated under no inoculated green manure plants (Table 3). For these treatments, dry matter of maize was improved on average for $20.34 \%$ compared to maize plant 
Table 1. Effect of inoculations with rhizobial (R) and arbuscular mycorrhizal (M) strains on aboveground dry matter (DM) and main considered nitrogen parameters of gliricidia plants cultivated for green manure production.

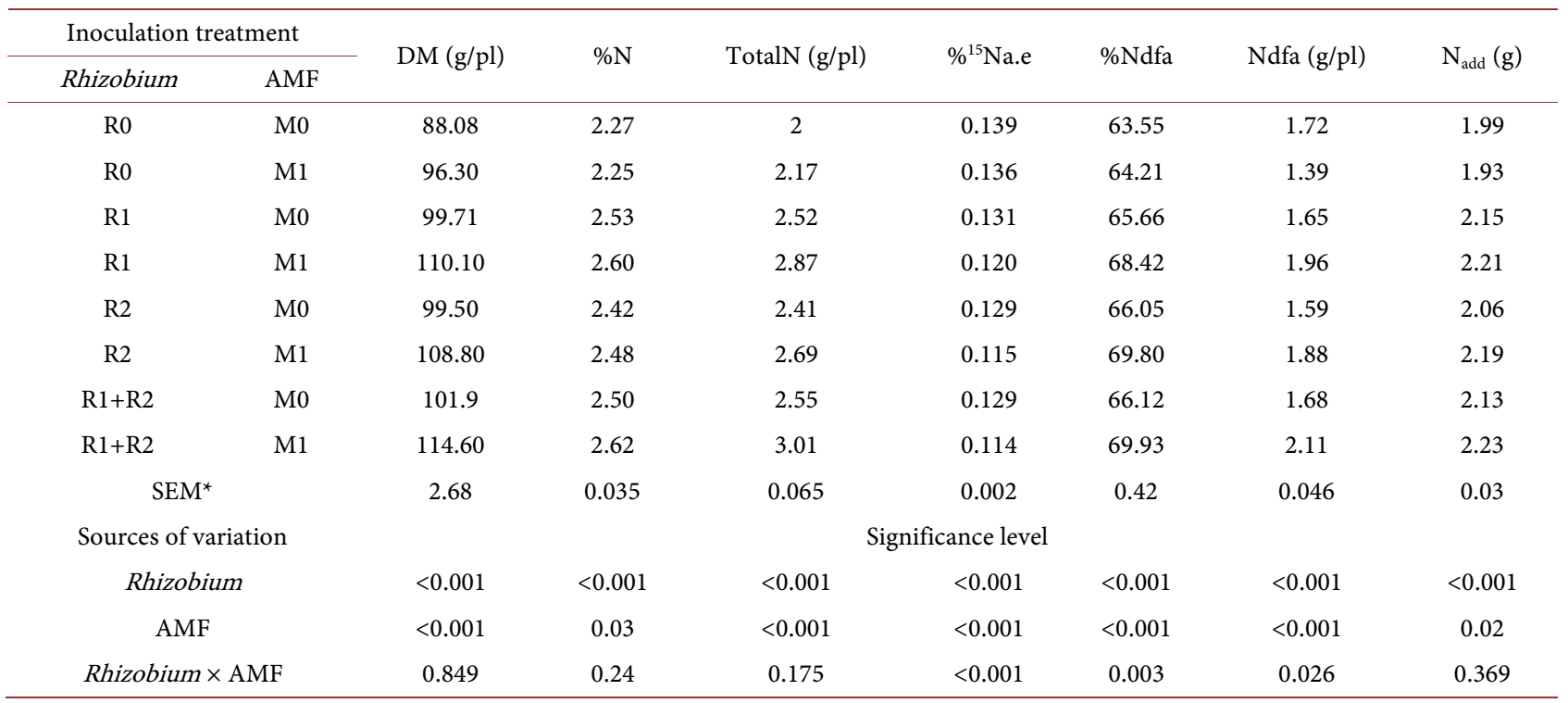

Table 2. Dry matter, percent and total $\mathrm{N}, 15 \mathrm{~N}$ enrichment, $\% \mathrm{~N}$ and $\mathrm{N}$ derived from green manure and $\mathrm{N}$ recovery of maize crop cultivated under gliricidia green manure.

Treatments applied on gliricidia used for green manure production

Maize crop cultivated under gliricidia green manure

\begin{tabular}{|c|c|c|c|c|c|c|c|c|}
\hline Rhizobium & $\mathrm{AMF}$ & $\mathrm{DM}(\mathrm{g} / \mathrm{pl})$ & $\% \mathrm{~N}$ & ${ }^{15} \%$ Na.e & Total N (g/pl) & $\%$ Ndfgm & Ndfgm (g/pl) & $\% \mathrm{~N}_{\text {rec }}$ \\
\hline R0 & M0 & 78.55 & 1.29 & 0.033 & 1.02 & 23.45 & 0.24 & 12.32 \\
\hline R0 & M1 & 80.03 & 1.38 & 0.033 & 1.11 & 23.73 & 0.27 & 13.58 \\
\hline R1 & M0 & 98.96 & 1.36 & 0.036 & 1.35 & 27.78 & 0.39 & 17.37 \\
\hline R1 & M1 & 102.30 & 1.48 & 0.039 & 1.52 & 32.72 & 0.50 & 22.42 \\
\hline $\mathrm{R} 2$ & M0 & 97.64 & 1.33 & 0.038 & 1.29 & 29.69 & 0.38 & 18.62 \\
\hline $\mathrm{R} 2$ & M1 & 99.81 & 1.52 & 0.037 & 1.52 & 32.51 & 0.50 & 23.50 \\
\hline $\mathrm{R} 1+\mathrm{R} 2$ & M0 & 98.64 & 1.43 & 0.037 & 1.41 & 28.93 & 0.41 & 19.24 \\
\hline $\mathrm{R} 1+\mathrm{R} 2$ & M1 & 99.84 & 1.69 & 0.040 & 1.69 & 35.01 & 0.59 & 26.52 \\
\hline \multicolumn{2}{|c|}{ SEM } & 1.95 & 0.02 & 0.001 & 0.03 & 0.89 & 0.02 & 0.79 \\
\hline \multicolumn{2}{|c|}{ Source of variation } & \multicolumn{7}{|c|}{ Significance level } \\
\hline \multicolumn{2}{|c|}{ Rhizobium } & $<0.001$ & $<0.001$ & $<0.001$ & $<0.001$ & $<0.001$ & $<0.001$ & $<0.001$ \\
\hline \multicolumn{2}{|c|}{$\mathrm{AMF}$} & 0.15 & $<0.001$ & 0.07 & $<0.001$ & $<0.001$ & $<0.001$ & $<0.001$ \\
\hline \multicolumn{2}{|c|}{ Rhizobium $\times$ AMF } & 0.947 & $<0.001$ & 0.082 & 0.053 & 0.014 & 0.002 & 0.008 \\
\hline
\end{tabular}

Table 3. Maize dry matter, total $\mathrm{N}$ and $\% 15 \mathrm{~N}$ affected by rhizobial inoculation of gliricidia for green manure production.

\begin{tabular}{cccc}
\hline \multirow{2}{*}{ Treatments for green manure production } & \multicolumn{3}{c}{ Maize plants } \\
\cline { 2 - 4 } & Dry matter $(\mathrm{g} / \mathrm{pl})$ & Total N content $(\mathrm{g} / \mathrm{pl})$ & $\%{ }^{15} \mathrm{Na} . e$. \\
\hline R0 & $79.29 \mathrm{~b}$ & $1.06 \mathrm{~d}$ & $0.0325 \mathrm{~b}$ \\
R1 & $100.67 \mathrm{a}$ & $1.43 \mathrm{~b}$ & $0.0378 \mathrm{a}$ \\
R2 & $98.72 \mathrm{a}$ & $1.41 \mathrm{bc}$ & $0.0377 \mathrm{a}$ \\
R1 + R2 & $99.24 \mathrm{a}$ & $1.55 \mathrm{a}$ & $0.0386 \mathrm{a}$ \\
\hline
\end{tabular}

For each column, values with the same letter are not significantly different at $\mathrm{p}<0.05$. 
amended with green manure obtained from no inoculated plant. Maize crop cultivated under green manure of gliricidia co-inoculated with mixed Rhizobium strains and AMF exhibited the highest $\mathrm{N}$ content (1.69\%) when the no inoculated plant produced the lowest biomass $\mathrm{N}$ content (1.29\%). Moreover, total $\mathrm{N}$ accumulation of maize dry matter was significantly influenced ( $\mathrm{p}<0.05 \%$ ) by rhizobial application on gliricidia for green manure production (on average $1.46 \mathrm{~g} / \mathrm{pl}$ ) when compared to maize plant cultivated under gliricidia aboveground biomass obtained without rhizobial inoculation $(1.06 \mathrm{~g} / \mathrm{pl})$ as exhibited on Table 3 .

\subsection{Proportion (\%N) and Amount of $\mathrm{N}$ Derived from Green Manure and \%N Recovery of Maize}

Analyse of variance performed on data from maize proportion (\%Ndfgm) and amount (Ndfgm) of nitrogen derived from green manure and the $\% \mathrm{~N}$ recovery of maize (Table 2) showed a significant interaction $(\mathrm{p}<0.05)$ between inoculation treatments for green manure production of gliricidia. Whatever the level of rhizobial inoculations for gliricidia biomass production, the proportion of $\mathrm{N}$ derived from green manure on maize crop was $24.61 \%$ higher than absolute control for which leguminous plant was not inoculated (Table 2, Figure 1(a)). Maize $\mathrm{N}$ derived from incorporated shoot dry matter of gliricidia was significantly increased by rhizobial and AMF strains inoculated for growth of gliricidia plants. Figure 1(b) exhibited that on average, the amount of Ndfgm for maize cultivated under biomass of gliricidia treated with microbial inoculations ( 0.53 $\mathrm{g} / \mathrm{pl})$ was highly greater than absolute control $(0.24 \mathrm{~g} / \mathrm{pl})$. Table 2 indicated that in presence of organic material produced with rhizobial inoculations, maize $\mathrm{N}$ recovery ranged from $17.32 \%$ to $26.52 \%$ of added $\mathrm{N}$, whatever the mycorrhizal fugus treatment. Maize $\% \mathrm{~N}$ recovery highest in plant cultivated under incorporation of green manure was affected by dual inoculation treatment (Figure 1(c)). Compared to maize plant control cultivated in soil amended with green manure produced without inoculation, maize recovered $49 \%$ higher when grown under amendment with treated dry matter production by inoculation with both Rhizobium and AMF strains (Table 2, Figure 1).

\section{Discussion}

\subsection{Gliricidia Green Manure Production}

Leguminous plants are used commonly in agricultural systems for maintaining soil fertility mainly as a source of $\mathrm{N}$ for subsequent crops. Gliricidia residues have been managed for improving sweet corn yield in and ultisol by nitrogen contribution from leaves pruning, roots and their mixture [12]. Gliricidia plants have a high significant ability to obtain its $\mathrm{N}$ requirement and improve its aboveground biomass through fixation [13]. Our present investigation showed that gliricidia aboveground biomass has been significantly increased by dual inoculation with rhizobial and AMF strains. Native rhizobial strain was included in this experiment to know more about their potential to promote $\mathrm{N}_{2}$ fixation in comparison to reference train TAL 1769. There were no sig- 


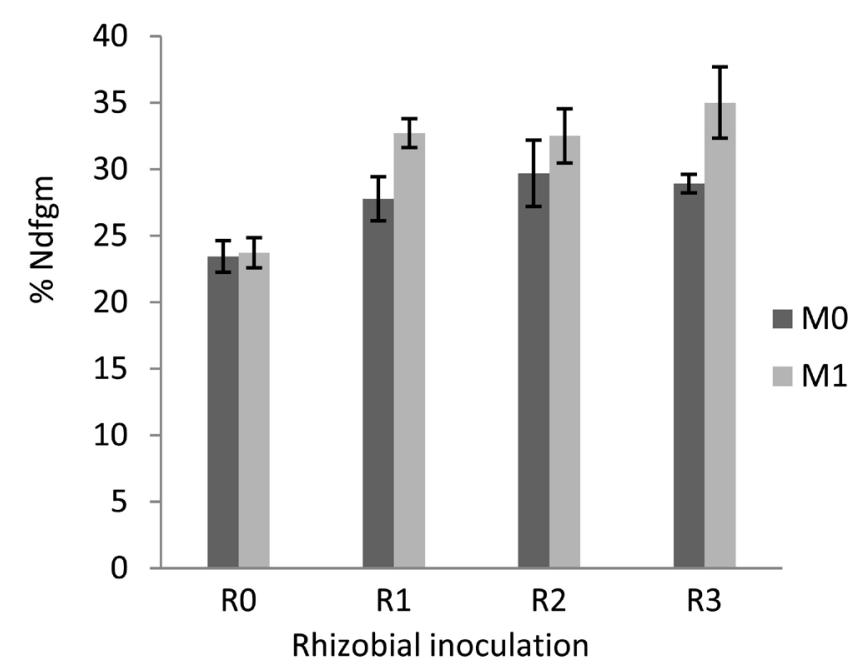

(a)

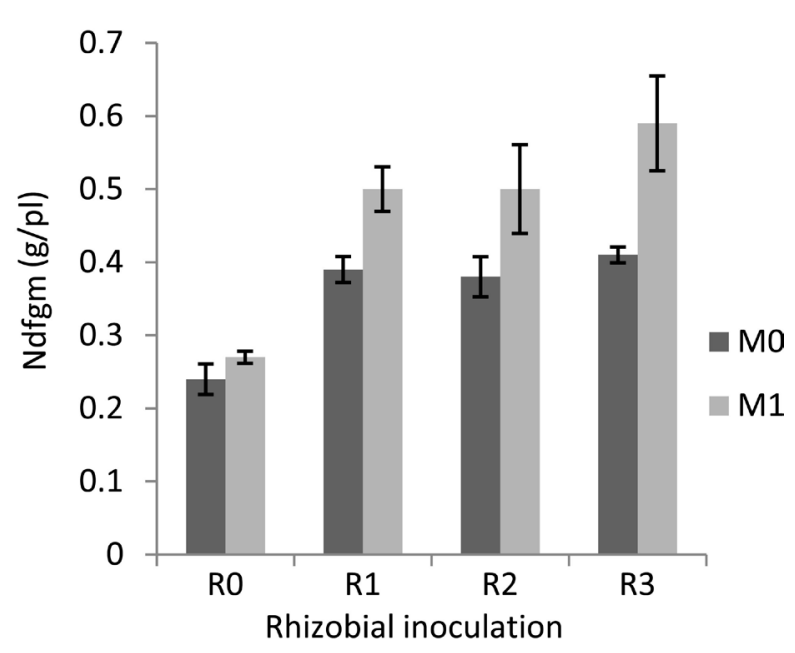

(b)

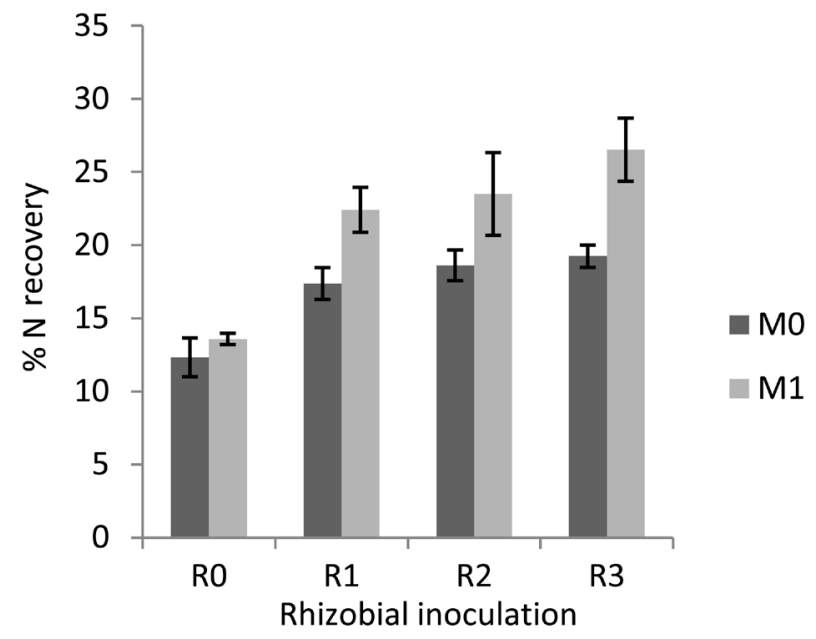

(c)

Figure 1. Interaction effect of rhizobial and mycorrhizal inoculation of gliricidia for green manure production on percentage (a) and amount (b) of nitrogen derived from green manure and $\% \mathrm{~N}$ recovery $(\mathrm{c})$ of maize cultivated under amendment.

nificant differences between exotic and native rhizobial strains, suggesting that growth of gliricidia plant in Senegalese soil didn't need use of foreign rhizobial strains for inoculation. Many investigations reported positive response of gliricidia trees to vesicular-arbuscular mycorrhizal and rhizobial infections [8] [14] [15]. Provided that efficient micro-symbionts are not or only in small amounts available in the soil, the $\mathrm{N}_{2}$ fixation activity can be increased by inoculation of the legume seeds or the soil [6] [16]. Positive influence of rhizobial inoculation on gliricidia shoot dry weight exhibited in this study matched with the results obtained on previous studies in similar experimental conditions [8]. Diouf et al. (2008a) reported that inoculations of gliricidia seedlings in a Sub-saharian sandy soil enhanced plant growth [8]. Remarkable increase of nitrogen content of pigeon pea has been earlier reported by dual inoculation of AMF and Rhizobium [17].

Due to the presence of infective indigenous rhizobia in the no-sterilized soil used in this study, nodulation and eventually nitrogen fixation occurred in all 
control plants of gliricidia. The ${ }^{15} \mathrm{~N}$ dilution techniques used in this study indicate a well $\mathrm{N}_{2}$-fixation of leguminous gliricidia regarding the reference plants. Our results indicated highly significant ${ }^{15} \mathrm{~N}$ enrichment on gliricidia aboveground biomass which was significant for its use as labelled organic matter on maize crop. Additionally, differences on atom $\%{ }^{15} \mathrm{~N}$ excess and on $\mathrm{N}$-fixed were of great significance to indicate potential impact of microbial inoculants on maize nutrient uptake from gliricidia green manure applied as fertilizer.

Nitrogen-fixing symbiotic bacteria and AMF contributed to the great nitrogen accumulation and high biomass production of gliricidia. The large amounts of $\mathrm{N}$-fixed by gliricidia in this study could be related to high aboveground biomass production. Similar results have been found in a field experiment by Rahman et al. (2009) on bean used for $\mathrm{N}$ fertilizer under rice-based cropping system [18]. The substantial $\mathrm{N}_{2}$-fixation in this experiment undertaken in greenhouse bearing out the previous result in the same conditions, Diouf et al., (2008) suggested that Gliricidia sepium should be an appropriate candidate to give similar or better results in $\mathrm{N}$-fixed in smallholders farming systems [8].

Plant biomass applied as soil amendment is subject to decomposition for releasing nutrient fertilizers in soil, depending on their biochemical composition [19] [20]. This needed suitable conditions and accurate time depending in part on plant species. Gliricidia plant aboveground biomass is reported to present a high decomposition rates. Schwendener et al., (2005) examined decomposition and $\mathrm{N}$ dynamics in mixtures of high-quality leguminous mulch, gliricidia with different ratio $\mathrm{C} / \mathrm{N}$ [21]. According to these authors more than $40 \%$ of the $\mathrm{N}$ in the gliricidia leaves had been released and a significant increase in available soil N occurred. Thus Hartemink and O'Sullivan, (2001) reported up to 50\% decomposition of the leaf biomass within 10 weeks with a high capacity to release $\mathrm{N}$ (79 kg N/ha) [22]. Also, Mensah et al, (2007) showed that leaf litter from the gliricidia treated plot recorded higher nitrogen up to $23.5 \%$, phosphorus and other nutrients compared to many plants used as controls in a field experiment [23]. All these previous results suggested that gliricidia biomass produced in this study should be a suitable organic material for amending maize cultivation in the Sub-Saharian sandy soil.

\subsection{Maize Cropping and N Uptake}

Luck of differences on shoot dry matter and atom $\%{ }^{15} \mathrm{~N}$ excess of maize cultivated in soil amended with gliricidia green manure whatever the rhizobial treatments on gliricidia plants suggested that there were no difference on efficiency of rhizobial strains applied as inoculant. This findings matched with results mentioned above on gliricidia inoculated indicating that there were no difference between indigenous and exotic reference strains of Rhizobium and their mode of applications. At that time, maize shoot dry weight was not subject to the effects of AMF inoculation which however highly influenced the amount of nitrogen in maize plants. Due to the higher proportion of $\mathrm{N}$ derived from $\mathrm{N}_{2}$ fixation in the AM-inoculated treatments, the amount of $\mathrm{N}_{2}$ fixed by gliricidia plants 
reflected closely the total $\mathrm{N}$ uptake by maize.

Cereal $\mathrm{N}$ accumulation and $\mathrm{N}$ in aboveground were assessed as key indicators for nitrogen use efficiency in cereal-based agro-ecosystems [24]. In our investigation the proportion and amount of $\mathrm{N}$ in maize crop derived from green manure and $\% \mathrm{~N}$ recovery by maize crop from applied gliricidia ${ }^{15} \mathrm{~N}$-labelled organic matter were evaluated and depended highly on the significant interaction between inoculation treatments for gliricidia aboveground biomass production. Maize crop cultivated under gliricidia organic matter exhibited a high growth rate estimated by plant shoot production. Nutrient release in soil from incorporated green manure sustained the high growth of maize which uptake nutrients mainly nitrogen from enriched soil. Maize nitrogen proportion derived from applied green manure ranged from $28 \%$ to $35 \%$. This represented the large amount of $\mathrm{N}$ accumulation in maize crop which reached $0.59 \mathrm{~g} \mathrm{~N} / \mathrm{pl}$. Due to the absence of inoculation, the control plants uptake only around $0.25 \mathrm{~g} \mathrm{~N} / \mathrm{pl}$. This significant difference in $\mathrm{N}$ accumulation of cereal crop was attributed to the positive effect of microbial inoculations applied on gliricidia leguminous plants cultivation.

The recovery rates of $\mathrm{N}$ from gliricidia aboveground biomass incorporated into the soil was influenced by the interaction of dual microbial inoculations. Therefore the main effect of rhizobial inoculation, which enhanced nitrogen uptake of the $\mathrm{N}$-fixing plant gliricidia (Table 2 ), was highly pronounced $(\mathrm{p}<0.001)$ suggesting its important role on $\mathrm{N}$ recovered by maize crop. The higher $\mathrm{N}$ concentrations of green manure produced under inoculation treatments compared to the non-inoculated explained the difference noted on maize $\mathrm{N}$ recovery from the gliricidia biomass. Due to the high rate of mineralization and biomass quality of gliricidia, an interesting percent of $\mathrm{N}$ recovery of maize crop, ranged from $17.37 \%$ to $26.52 \%$ was recorded whatever the level of inoculation. Otherwise, in our study, the variation of $Z$. mays $\mathrm{N}$ recovered from gliricidia biomass depends on inoculation treatments. The lowest maize $\% \mathrm{~N}$ recovery $(12.32 \%)$ was recorded when maize crop received green manure produced without inoculation (absolute control). On average, the greatest $\% \mathrm{~N}$ recovery of maize crop $(24.15 \%)$ from organic fertilizer was obtained when gliricidia plants were co-inoculated. The increase in fertilizer $\mathrm{N}$ uptake appeared to be related to incorporated biomass produced under rhizobial and mycorrhizal inoculations treatments. Whatever the level of gliricidia green manure amendment, a high average of $\mathrm{N}$ recovered by maize (19.20\%) was obtained. Therefore, Haggar et al. (1993) reported that mulch $\mathrm{N}$ released during a cropping season accounted for about $15 \%$ of the increase in $\mathrm{N}$ uptake by maize crop [25]. Despite this high level of $\mathrm{N}$ recovery, the added organic matter was not completely decomposable due to the short cropping time which didn't allow complete mineralization of all biomass applied. This situation suggested a possible release into the soil of substantial remaining $\mathrm{N}$ in organic matter that contributes to soil $\mathrm{N}$ enrichment which will be available for succeeding crops. Results of Douxchamps et al. (2011) revealed that most of the amendment $\mathrm{N}$ remained in the soil for maize cultivation under in- 
corporation of canavalia residues which allowed N recovery of 12\% [26]. Nygren et al. (2012) reported that leaf litter and green mulch applications release $\mathrm{N}$ slowly to the soil and mostly benefit the crop through long-term soil improvement [27]. In this way, Ambrosano et al. (2013) suggested that legume residue decomposition provided long-term supply of $\mathrm{N}$ for the subsequent crops, by not supplying the nutrient as an immediate source [28]. High quality of gliricidia biomass produced under inoculation with symbiotic microorganisms enhanced $\mathrm{N}$ uptake and growth of maize. These results have to be confirmed in multilocational trials in farmer's fields in comparison to conventional farms for more knowledge on its impacts on grain production as reported by Diouf et al. (2008) in a greenhouse experiment [8].

\section{Conclusion}

Gliricidia biomass and its nitrogen accumulation through biological nitrogen fixation are significantly enhanced by dual inoculation with rhizobium and arbuscular mycorrhizal fungus. Incorporation of gliricidia organic matter in sandy soil improves mineral nutrition of cultivated maize crop. The labelled ${ }^{15} \mathrm{~N}$ showed that green manure $\mathrm{N}$ is released in soil and uptake by cultivated maize such as indicated by its $\mathrm{N}$ recovered. Gliricidia organic matter should be suitable for amending maize cultivation in the Sub-Saharian sandy soil.

\section{Acknowledgements}

The authors thank International Atomic Energy Agency (IAEA) for supporting fellowship on Agricultural Water Management at Soil and Water Management and Crop Nutrition Laboratory, Seibersdorf through project SEN5030. The authors gratefully acknowledge Omar TOURE for his technical assistance.

\section{References}

[1] FAO (1985) Changes in Shifting Cultivation in Africa: Seven Case Studies. FAO Forestry, Paper 50/1, FAO, Rome.

[2] Camara, K.M., Payne, W.A. and Rasmussen, P.E. (2003) Long-Term Effects of Tillage, Nitrogen, and Rainfall on Winter Wheat Yields in the Pacific Northwest. Agronomy Journal, 95, 828-835. https://doi.org/10.2134/agronj2003.0828

[3] Kidd, P.S., Dominguez-Rodriguez, M.J., Diez, J. and Monterroso, C. (2007) Bioavailability and Plant Accumulation of Heavy Metals and Phosphorus in Agricultural Soils Amended by Long-Term Application of Sewage Sludge. Chemosphere, 66, 1458-1467. https://doi.org/10.1016/j.chemosphere.2006.09.007

[4] Bationo, A., Sanginga, N., Vanlauwe, B., Waswa, B. and Kihara, J. (2008) Evaluation of Long Term Agroforestry Soil Fertility Management in Derived Savanna in West Africa. Management of Agroforestry Systems for Enhancing Resource Use Efficiency and Crop Productivity, IAEA-TECDOC-1606.

[5] Ambrosano, E.J., Trivelin, P.C.O., Cantarella, H., Ambrosano, G.M.B., Schammass, E.A., Guirado, N., Rossi, F., Mendes, P.C.D. and Muraoka, T. (2005) Utilization of Nitrogen from Green Manure and Mineral Fertilizer by Sugarcane. Scientia Agricola, 62, 534-542. https://doi.org/10.1590/S0103-90162005000600004

[6] Hardarson, G. and Atkins, C. (2003) Optimising Biological N2 Fixation by Legumes 
in Farming Systems. Plant and Soil, 252, 41-54.

https://doi.org/10.1023/A:1024103818971

[7] Conant, R.T., Berdanier, A.B. and Grace, P.R. (2013) Patterns and Trends in Nitrogen Use and Nitrogen Recovery Efficiency in World Agriculture. Global Biogeochemical Cycles, 27, 558-566. https://doi.org/10.1002/gbc.20053

[8] Diouf, A., Diop, T.A., Ndoye, I. and Gueye, M. (2008) Response of Gliricidia sepium Tree to Phosphorus Application and Inoculations with Glomus aggregatum and Rhizobial Strains in a Sub-Saharian Sandy Soil. African Journal of Biotechnology, 7, 766-771.

[9] Diouf, A., Diop, T.A., Fall-Ndiaye, M.A. and Gueye, M. (2008) Impact de la biomasse de Gliricidia sepium utilisée comme engrais vert sur la culture du maïs (Zea mays L.) au Sénégal. Journal des Sciences, 8, 10-17.

[10] Fried, M. and Middelboe, V. (1977) Measurement of the Amount of Nitrogen Fixed by a Legume Crop. Plant Soil, 47, 713-715. https://doi.org/10.1007/BF00011042

[11] Hauck, P.B.S. and Bremner, J.M. (1976) Use of Tracers for Soil and Fertiliser Nitrogen Research. Advances in Agronomy, 28, 219-266. https://doi.org/10.1016/S0065-2113(08)60556-8

[12] Zaharah, A.R. and Bah, A.R. (1999) Patterns of Decomposition and Nutrient Release by Fresh Gliricidia (Gliricidia sepium) Leaves in Ultisol. Nutrient Cycling in Agroecosystems, 55, 269-277. https://doi.org/10.1023/A:1009803410654

[13] Gunaratne, W.D.L., Heenkenda, A.P., Premakumaraand, K.V.S. and Bandara, W.M.S.R. (2000) Biological $\mathrm{N}_{2}$ Fixing Capacity of Gliricidia sepium and Calliandra calothyrsus under Different Agroclimatic Conditions. Tropical Agricultural Research and Extension, 3, 32-38.

[14] Habte, M. and Turk, D. (1991) Response of Two Species of Cassia and Gliricidia sepium to Vesicular-Arbuscular Mycorrhizal Infection. Communications in Soil Science \& Plant Analysis, 22, 17-18. https://doi.org/10.1080/00103629109368541

[15] Liyanage, M.S., Danso, S.K.A. and Jayasundara, H.P.S. (1994) Biological Nitrogen Fixation in Four Gliricidia sepium Genotypes. Plant and Soil, 161, 267-274. https://doi.org/10.1007/BF00046398

[16] Diouf, A., Ndoye, I., Spencer, M.M., Nef-Campa, C. and Gueye, M. (1999) Need for Inoculation of Common Bean (Phaseolus vulgaris L.) in Senegal and Assessment of Nitrogen Fixation Using 15N Isotope Dilution Technique. Symbiosis, 27, 251-257.

[17] Bhattacharjee, S. and Sharma, G. D. (2012) Effect of Dual Inoculation of Arbuscular Mycorrhiza and Rhizobium on the Chlorophyll, Nitrogen and Phosphorus Contents of Pigeon Pea (Cajanus cajan L.). Advances in Microbiology, 2, 561-564. https://doi.org/10.4236/aim.2012.24072

[18] Rahman, M.M., Amano, T. and Shiraiwa, T. (2009) Nitrogen Use Efficiency and Recovery from N Fertilizer under Rice-Based Cropping Systems. Australian Journal of Crop Science, 3, 336-351.

[19] Abiven, S., Recous, S., Reyes, V. and Oliver, R. (2005) Mineralization of C and N from Root, Stem and Leaf Residues in Soil and Role of Their Biochemical Quality. Biology and Fertility of Soils, 42, 119-128. https://doi.org/10.1007/s00374-005-0006-0

[20] Zhang, D., Hui, D., Luo, Y. and Zhou, G. (2008) Rates of Litter Decomposition in Terrestrial Ecosystems: Global Patterns and Controlling Factors. Journal of Plant Ecology, 1, 85-93. https://doi.org/10.1093/jpe/rtn002

[21] Schwendener, C.M., Lehmann, J., De Camargo, P.B., Luizao, R.C.C. and Fernandes, E.C.M. (2005) Nitrogen Transfer between High- and Low-Quality Leaves on a Nu- 
trient-Poor Oxisol Determined by $15 \mathrm{~N}$ Enrichment. Soil Biology \& Biochemistry, 37, 787-794. https://doi.org/10.1016/j.soilbio.2004.10.011

[22] Hartemik, A.E. and O’Sullivan, J.N. (2001) Leaf Litter Decomposition of Piper aduncum, Gliricidia sepium and Imperata cylindrica in the Humid Lowlands of Papua New Guinea. Plant and Soil, 230, 115-124. https://doi.org/10.1023/A:1004868502539

[23] Mensah, J.K., Akomeah, P.A. and Eifediyi, E.K. (2007) Soil Fertility Regeneration of Impoverished Ultisols of Edo State Using Gliricidia sepium Jacq Walp. Journal of Agronomy, 6, 593-596. https://doi.org/10.3923/ja.2007.593.596

[24] Huggins, D.R. and Pan, W.L. (2003) Key Indicators for Assessing Nitrogen Use Efficiency in Cereal-Based Agro-Ecosystems. Journal of Crop Production, 8, 157-185. https://doi.org/10.1300/J144v08n01_07

[25] Haggar, J.P., Tanner, E.V.J., Beer, J.W. and Kass, D.C.L. (1993) Nitrogen Dynamics of Tropical Agroforestry and Annual Cropping Systems. Soil Biology and Biochemistry, 25, 1363-1378. https://doi.org/10.1016/0038-0717(93)90051-C

[26] Douxchamps, S., Frossard, E., Bernasconi, S.M., Hoek, R., Schmidt, A., Rao, I.M. and Oberson, A. (2011) Nitrogen Recoveries from Organic Amendments in Crop and Soil Assessed by Isotope Techniques under Tropical Field Conditions. Plant Soil, 341, 179-192. https://doi.org/10.1007/s11104-010-0633-6

[27] Nygren, P., Fernández, M.P., Harmand, J.M. and Leblanc, H.A. (2012) Symbiotic Dinitrogen Fixation by Trees an Underestimated Resource in Agroforestry Systems? Nutrient Cycling in Agroecosystems, 94, 123-160. https://doi.org/10.1007/s10705-012-9542-9

[28] Ambrosano, E.J., Cantarella, H., Ambrosano, G.M.B., Dias, F.L.F., Rossi, F., Trivelin, P.C.O. and Muraoka, T. (2013) The Role of Green Manure Nitrogen Use by Corn and Sugarcane Crops in Brazil. Agric Sciences, 4, 89-108. https://doi.org/10.4236/as.2013.412A008

\section{Submit or recommend next manuscript to SCIRP and we will provide best} service for you:

Accepting pre-submission inquiries through Email, Facebook, LinkedIn, Twitter, etc. A wide selection of journals (inclusive of 9 subjects, more than 200 journals)

Providing 24-hour high-quality service

User-friendly online submission system

Fair and swift peer-review system

Efficient typesetting and proofreading procedure

Display of the result of downloads and visits, as well as the number of cited articles

Maximum dissemination of your research work

Submit your manuscript at: http://papersubmission.scirp.org/

Or contact ajps@scirp.org 